\title{
EFFICACY OF NEGATIVE PRESSURE WOUND THERAPY IN EARLY DIABETIC FOOT ULCER MANAGEMENT IN COMPARISON WITH ADVANCED MOIST WOUND THERAPY
}

\author{
Naveed Ahmed Sheen, Ali Murtaza Samar*, Muhammad Ibrar Butt**, Zeeshan Ayub ${ }^{* * *}$, Faisal Nadeem**** \\ Combined Military Hospital Sibi/National University of Medical Sciences Pakistan, *Salisbury District Hospital, Salisbury United Kingdom, **Islam Teaching \\ Hospital, Sialkot Pakistan, ${ }^{* * *}$ Combined Military Hospital Quetta/National University of Medical Sciences Pakistan, ${ }^{* * *}$ Frontier Corps Hospital, Chitral Pakistan
}

\begin{abstract}
Objective: To compare negative pressure wound therapy with advanced moist wound therapy in managing early diabetic foot ulcer.

Study Design: Quasi-experimental study.

Place and Duration of Study: Surgical Department, Combined Military Hospital Rawalpindi, from Jul 2016 to Jun 2018.

Methodology: A total of 100 patients of diabetic foot ulcer were randomly allocated into two equal groups for the treatment with negative pressure wound therapy (NPWT) and advanced moist wound therapy (AMWT). Ulcers were reassessed after 4 weeks for presence of granulation tissue covering entire ulcer base and reduction of $3 \mathrm{~cm}$ in largest diameter of ulcer.

Results: Mean age of the study participants was $57.08 \pm 9.99$ years. Thirty-three patients had Wagner grade-I ulcer, while remaining had Wagner grade-II ulcer. Mean ulcer size at presentation was $6.46 \pm 1.71 \mathrm{~cm}$. Both study groups were comparable in terms of mean age $(p=0.968)$, wound size at presentation $(p=1.000)$, age $(p=0.695)$, gender $(p=1.000)$ and Wagner ulcer grade $(p=0.288)$. Mean ulcer size was found smaller with negative pressure wound therapy $(3.46 \mathrm{~cm}, p=0.061)$ at follow-up visits. Reduction in ulcer size $\geq 3 \mathrm{~cm}$ was achieved frequently with negative pressure wound therapy technique (72\% vs. $38 \% ; p>0.01)$. Mean healing time was $4.11 \pm 1.65$ weeks which was lower with negative pressure wound therapy (3.66 weeks vs. 4.56 weeks; $p>0.05$ ). Treatment efficacy (healing in $\leq 4$ weeks and $\geq 3 \mathrm{~cm}$ reduction in ulcer) was significantly higher with negative pressure wound therapy $(72.0 \%$ vs. $38.0 \% ; p<0.01)$ as well.

Conclusion: This study demonstrates superiority of negative pressure wound therapy over advanced moist wound therapy in diabetic foot ulcer management.
\end{abstract}

Keywords: Advanced moist wound therapy, Diabetes, Foot ulcer, Negative pressure wound therapy, Wound.

How to Cite This Article: Sheen NA, Samar AM, Butt MI, Ayub Z, Nadeem F. Efficacy of Negative Pressure Wound Therapy in Early Diabetic Foot Ulcer Management in Comparison with Advanced Moist Wound Therapy. Pak Armed Forces Med J 2021; 71(6): 2087-2090. D Doi: https://doi.org/10.51253/pafmj.v6i6.6231

This is an Open Access article distributed under the terms of the Creative Commons Attribution License (https://creativecommons.org/licenses/by-nc/4.0/), which permits unrestricted use, distribution, and reproduction in any medium, provided the original work is properly cited.

\section{INTRODUCTION}

Diabetes Mellitus is one of the leading health issues in Pakistan with prevalence of 11 million in 2012, with projected numbers to reach 642 million by year 2040.1 The risk of developing a diabetic foot ulcer in these patients stand around $25 \%$ in the individual's lifetime. Although, $8.2 \%$ of the population suffer from diabetes mellitus, nearly half of all non-traumatic lower extremity amputations entail from diabetic foot ulcers owing to the nature of this chronic disease entity. ${ }^{2}$ It is indeed pertinent to mention that even post amputation, the 5-year survival rate stands at mere $40 \%$ in such cases. ${ }^{3}$ Infections in diabetic foot range from fungal infections of the nails to necrotizing limb threatening infections. ${ }^{4}$ Development of non-healing diabetic foot is attributed to interplay among varying factors like immune dysfunction, atherosclerotic peripheral arterial disease and delayed detection due to peripheral neuropathy and retinopathy. ${ }^{5}$

Correspondence: Dr Naveed Ahmed Sheen, Surgical OPD, Combined Military Hospital, Sibi Pakistan

Received: 31 Jan 2021; revision received: 12 Mar 2021; accepted: 15 Mar 2021
The mainstay of treatment for diabetic foot ulcer stands at the crossroads of efficient glycaemic control, debridement of all necrotic and fibrous tissue with an aim to achieve primary closure of the wound, appropriate antibiotics and provision of moist wound environment as required. ${ }^{6}$ The main determinants considered while tailoring the management plan are ulcer grade (Wagner Classification), glycaemic control, patency of limb vascularity and the presence of infection. ${ }^{7}$ The ambiguity around the optimal topical treatment for diabetic foot ulcer still remains. The standard treatment has been saline-moistened gauze with frequent multiple daily dressings. In order to counter the compliance issues, various impermeable hydrocolloid wound gels (also known as advanced moist wound therapy-AMWT) have been developed to ensure the persistent moist environment. ${ }^{8}$

Negative pressure wound therapy (NPWT) also known as vacuum assisted closure (VAC) technique is an emerging therapy which functions by creation of negative sub atmospheric pressure at the ulcer site. ${ }^{9}$ Its beneficial effects are rendered by continuous sub 
atmospheric pressure, created by a specified pump, which in turn, is connected to the resilient, foam-surface formed by saline and hydrogen peroxide soaked dressing that serves to collect the wound exudates and pathogens. Moreover, it exerts positive mechanical effects on both the wound contraction and the proliferation of granulation tissue. ${ }^{10}$ The limited local literature on negative pressure wound therapy drove us towards this study. The use of negative pressure wound therapy cannot only limit the healing time but can serve as a low-cost solution. Thus, this study was planned to compare efficacy of negative pressure wound therapy with hydrocolloid dressing (advanced moist wound therapy) to treat diabetic foot ulcers in our target population.

\section{METHODOLOGY}

This study was carried out in the Department of General Surgery, Combined Military Hospital, Rawalpindi Pakistan from July 2016 to June 2018 after due permission from institutional ethical committee (IERB certificate number A/45/2016). The aim was to compare negative pressure wound therapy (NPWT) dressing with advanced moist wound therapy (AMWT) in managing diabetic foot ulcer. A sample size of 100 patients was calculated using World Health Organization (WHO) sample size calculator keeping Level of significance $=5 \%$, Power of the test $=80 \%$ and anticipated population prévalence $78.6 \%{ }^{11}$ Patients were selected by non-probability consecutive sampling.

Inclusion Criteria: All adults of either gender with diabetes, aged 18-60 years, with calcaneal, dorsal or plantar foot ulcers (Wagner Grade 1 or 2 as mentioned in Table-I) were enrolled into the study.

\begin{tabular}{c|c}
\multicolumn{2}{c}{ Table-I: Wagner Ulcer Classification 12. } \\
\hline Grade & Lesion \\
\hline 0 & Preulcerative lesion, foot at risk \\
\hline 1 & Superficial diabetic ulcer \\
\hline 2 & $\begin{array}{c}\text { Ulcer extension involving ligament, tendon, joint } \\
\text { capsule, or fascia with no abscess or osteomyelitis }\end{array}$ \\
\hline 3 & Deep ulcer with soft tissue abscess or osteomyelitis \\
\hline 4 & Localized gangrene to portion of forefoot \\
\hline 5 & Extensive gangrene of foot \\
\hline
\end{tabular}

Exclusion Criteria: Patients with ulcers resulting from burns, with ulcer malignancy or untreated osteomyelitis were excluded.

The wound measurement technique involved placement of a transparent sheet across the wound surface and then tracing its margins with indelible ink. The dimensions were then determined by using ruler to measure the tracing of the wound. Patients were elaborately apprised about the study and informed written consent was sought from each of them.

The patients were divided into two equal groups by lottery method - advanced moist wound therapy in group A while in group B, negative pressure wound therapy was applied. After ulcer debridement in both groups, digital photographs were taken and largest dimension of ulcer was recorded. Advanced moist wound therapy moist dressings were changed on a daily basis using hydrocolloid wound gel and gauze dressing was applied. Negative pressure wound therapy dressing was changed after every 48 hours. The ulcer status was reassessed at two and four week intervals in two ways-presence or absence of granulation tissue covering the entire ulcer base and reduction in ulcer size of at least $3 \mathrm{~cm}$ in its largest diameter was assessed. All the information was recorded on the specially designed proforma.

Statistical analysis was performed using Statistical Package for the social sciences (SPSS) version 23 for quantitative as well as qualitative variables. Independent sample t-test was applied to compare wound healing and to compare the decrease in ulcer size between the two groups. The $p$-value of $\leq 0.05$ was considered as significant.

\section{RESULTS}

Overall, 100 patients were enrolled in the study. The age of the patients ranged from 18 years to 60 years with mean of $57.08 \pm 9.99$ years. There were 88 male and 12 female patients in the study. In 33 patients, diabetic foot ulcer was Wagner grade- 1 while in the remaining 67 cases it was Wagner grade- 2 ulcer. The ulcer size ranged from $4 \mathrm{~cm}$ to $9 \mathrm{~cm}$ with a mean of $6.46 \pm 1.71 \mathrm{~cm}$. Both the study groups were comparable in terms of mean age, wound size at presentation, gender and Wagner ulcer grade as depicted in Table-II.

The mean ulcer size at follow-up was lower in negative pressure wound therapy group $(3.46 \pm 1.66$ cm vs. $4.14 \pm 1.92 \mathrm{~cm} ; p=0.061$ ) as compared with advanced moist wound therapy group. The mean reduction in ulcer size was significantly more in the negative pressure wound therapy group $(3.00 \pm 0.81 \mathrm{~cm}$ vs. 2.32 $\pm 1.02 \mathrm{~cm} ;(p<0.01)$ as compared to advanced moist wound therapy group as shown in Table-III. The number of patients found to have at least reduction of more than $3 \mathrm{~cm}$ in ulcer size in the greatest dimension was significantly higher in negative pressure wound therapy group $(72.0 \%$ vs. $38.0 \% ; p<0.01)$ as compared to advanced moist wound therapy group. Healing time 
ranged from 2-7 weeks with a mean of $4.11 \pm 1.65$ weeks. It was significantly lower in negative pressure wound therapy group ( $3.66 \pm 1.47$ weeks vs. $4.56 \pm 1.70$ weeks; $p<0.01)$ as compared to advanced moist wound therapy group. The frequency of healing in 4 weeks was significantly higher in negative pressure wound therapy group ( $78 \%$ vs. $46 \% ; p<0.01$ ) as compared to advanced moist wound therapy group.

\begin{tabular}{|c|c|c|c|}
\hline \multicolumn{2}{|c|}{ Characteristics } & \multirow{2}{*}{$\begin{array}{c}\text { Group 1- } \\
\text { Advanced } \\
\text { Moist Wound } \\
\text { Therapy n (\%) } \\
3(6 \%)\end{array}$} & \multirow{2}{*}{$\begin{array}{c}\text { Group 2 - } \\
\text { Negative } \\
\text { Pressure Wound } \\
\text { Therapy n (\%) } \\
4(8 \%) \\
\end{array}$} \\
\hline \multirow{3}{*}{$\begin{array}{l}\text { Age } \\
\text { (years) }\end{array}$} & $<40$ & & \\
\hline & $\geq 40$ & $47(94 \%)$ & $46(92 \%)$ \\
\hline & Mean \pm SD & $57.12 \pm 9.83$ & $57.04 \pm 10.25$ \\
\hline \multirow{2}{*}{ Gender } & Male & $44(88 \%)$ & $44(88 \%)$ \\
\hline & Female & $6(12 \%)$ & $6(12 \%)$ \\
\hline \multirow{2}{*}{$\begin{array}{l}\text { Wagner } \\
\text { Ulcer } \\
\text { Grading }\end{array}$} & Grade 1 & $19(38 \%)$ & $14(28 \%)$ \\
\hline & Grade 2 & $31(62 \%)$ & $36(72 \%)$ \\
\hline \multicolumn{2}{|c|}{$\begin{array}{l}\text { Ulcer size at } \\
\text { presentation }(\mathrm{cm})\end{array}$} & $6.46 \pm 1.73$ & $6.46 \pm 1.71$ \\
\hline
\end{tabular}

Table-III: Comparison of ulcer healing between the study groups $(\mathbf{n}=100)$.

\begin{tabular}{l|c|c|c}
\hline Characteristics & $\begin{array}{c}\text { Group 1- } \\
\text { Advanced } \\
\text { Moist Wound } \\
\text { Therapy (n=50) }\end{array}$ & $\begin{array}{c}\text { Group 2 - } \\
\text { Negative } \\
\text { Pressure Wound } \\
\text { Therapy (n=50) }\end{array}$ & $\begin{array}{c}p \text { - } \\
\text { value }\end{array}$ \\
\hline $\begin{array}{l}\text { Ulcer Size at } \\
\text { Follow-up (cm) }\end{array}$ & $4.14 \pm 1.92$ & $3.46 \pm 1.66$ & 0.061 \\
\hline $\begin{array}{l}\text { Reduction in } \\
\text { Ulcer Size (cm) }\end{array}$ & $2.32 \pm 1.02$ & $3.00 \pm 0.81$ & $<0.01$ \\
\hline $\begin{array}{l}\text { Reduction of } \\
\text { Ulcer Size }>3 \mathrm{~cm}\end{array}$ & $19(38 \%)$ & $36(72 \%)$ & $<0.01$ \\
\hline $\begin{array}{l}\text { Wound Healing } \\
\text { Time (weeks) }\end{array}$ & $4.56 \pm 1.70$ & $3.66 \pm 1.47$ & $<0.01$ \\
\hline $\begin{array}{l}\text { Wound Healing } \\
\text { in 4 weeks }\end{array}$ & $23(46 \%)$ & $39(78 \%)$ & $<0.01$ \\
\hline
\end{tabular}

The treatment efficacy (healing in $\leq 4$ weeks and reduction in ulcer size $\geq 3 \mathrm{~cm}$ ) was significantly higher in negative pressure wound therapy group $(72.0 \%$ vs. $38.0 \% ; p<0.01)$ as compared to advanced moist wound therapy group. Similar difference was observed across Wagner ulcer grades as shown in Table-IV.

\section{DISCUSSION}

Diabetes Mellitus has an ever-rising prevalence and it poses a major public health problem in a resource constraint health system of Pakistan. ${ }^{1}$ Aging, physical inactivity, obesity, genetic predisposition and poor eating habits with increased consumption of lowcost high calorie foods account for the rising incidence of diabetes mellitus. Owing to its chronicity and asso- ciated complications, diabetic foot ulcers are the most feared complications. They account for more in hospital care than any other diabetes related complication and are responsible for about $25 \%$ of the total health care expenditure among diabetic populations. All the patients harboring diabetic foot ulcers need a coherent multidisciplinary approach. ${ }^{13}$

Our study included Wagner grade 1 and 2 ulcers. Favourable outcome was measured in terms of granulation formation on the entire wound base and reduction in ulcer size by 3 centimeters in its largest diameter within four weeks of treatment. Granulation formation was seen in 23 patients of group A (advanced moist wound therapy) and 39 patients of group B (negative pressure wound therapy), whereas reduction in size of the ulcer was achieved in 19 cases of advanced moist wound therapy vs 36 patients of negative pressure wound therapy. This result was found to be statistically significant which led us to the conclusion than negative pressure wound therapy is a better alternative to costly and prolonged advanced moist wound therapy.

Table-IV: Comparison of treatment efficacy across the study groups $(\mathrm{n}=100)$.

\begin{tabular}{|c|c|c|c|c|}
\hline \multirow{2}{*}{\multicolumn{2}{|c|}{$\begin{array}{l}\text { Wagner } \\
\text { Grade } \\
\text { Efficacy }\end{array}$}} & $\begin{array}{c}\text { Group 1- } \\
\text { Advanced Moist } \\
\text { Wound Therapy, } \\
n=50(\%)\end{array}$ & \begin{tabular}{|c|} 
Group 2 - \\
Negative Pressure \\
Wound Therapy, \\
$n=50(\%)$
\end{tabular} & \multirow[t]{2}{*}{$\begin{array}{c}p- \\
\text { value }\end{array}$} \\
\hline & & $\mathrm{n}(\%)$ & $\mathrm{n}(\%)$ & \\
\hline \multirow{4}{*}{$\begin{array}{l}\text { Grade } 1 \\
(n=33) \\
\text { Grade } 2 \\
(n=67)\end{array}$} & Yes & $7(36.8 \%)$ & $11(78.6 \%)$ & \multirow{2}{*}{0.017} \\
\hline & No & $12(63.2 \%)$ & & \\
\hline & Yes & $12(38.7 \%)$ & $25(69.4 \%)$ & \multirow{2}{*}{0.012} \\
\hline & No & $19(61.3 \%)$ & $11(30.6 \%)$ & \\
\hline
\end{tabular}

Nain et al. applied the principle of negative pressure wound therapy as compared to saline dressings in 30 patients. Although wound recovery was there in both groups, negative pressure wound therapy patients displayed statistically better outcome than saline dressing group on serial assessments, especially more remarkably in terms of reduction of bacterial load. ${ }^{14}$

Ravari et al, in a prospective study of 23 patients with diabetic foot ulcers of Wagner grade 1-4 showed better outcome of patients treated with Negative pressure wound therapy as compared to advanced moist wound therapy both in terms of wound healing and patient satisfaction. $70 \%$ had formation of granulation tissue after 2 weeks of treatment with VAC (negative pressure wound therapy) as against the $50 \%$ response in moist dressing group. ${ }^{15}$ 
Meo et al, studied a group of 60 patients with diabetic lower limb ulcers. Thirty patients were treated with negative pressure wound therapy and the wound was studied with reference to granulations. The negative pressure wound therapy group performed statistically better in wound healing as compared to the traditional dressings. ${ }^{1}$

Vacuum therapy or negative pressure wound therapy provides an occlusive environment to the ulcer area, which in turn renders sterile, moist clean conditions. ${ }^{16}$ This promotes arteriolar dilatation thereby enhancing local circulation, which helps to wash off toxins, increases angiogenesis with more growth factor concentration at the wound site. Such a sterile moist environment cannot be maintained with conventional dressing means. ${ }^{17}$ Moreover, negative pressure wound therapy tends to draw the wound edges inwards resulting in shrinkage of the wound from the wound edges causing a better re-epithelialization of the ulcer. ${ }^{18}$ Hence, negative pressure wound therapy is valuable intervention either to achieve secondary wound healing or to prepare wound for skin grafting or flap application.

We recommend including baseline arterial duplex scan and another scan at 6 weeks in future studies, which were not uniformly performed, in our patients.

\section{LIMITATION OF STUDY}

Limitations of this study include unavailability of comorbidity data including smoking, hypertension, retinopathy and peripheral vascular disease as these factors adversely affect the healing of any diabetic foot ulceration. Comparison of quality of life, post-treatment extremity functional status and patient satisfaction would have provided more comprehensive outcome measures. Validation of these results by multi center trials can help in standardizing the treatment of diabetic foot ulcers.

\section{CONCLUSION}

This study has demonstrated that negative pressure wound therapy dressing technique is more efficacious in wound healing and decreases the wound size as compared with advanced moist wound therapy in the management of diabetic foot ulcers.

\section{Conflict of Interest: None.}

\section{Authors' Contribution}

NAS: Study conception, design, acquisition, analysis and interpretation of data, AMS: Drafting of mauscript, Analysis and interpretation of data \& critical revision, MIB: Drafting of mauscript \& analysis is and inter pretation of data, ZA: Study conception and design, drafting of mauscript, FN: Acquisition of data \& drafting of manuscript.

\section{REFERENCES}

1. Meo SA, Zia I, Bukhari IA, Arain SA. Type 2 diabetes mellitus in Pakistan: Current prevalence and future forecast. J Pak Med Assoc 2016; 66(12): 1637-1642.

2. Dumville JC, Soares MO, Meara SO, Cullum N. Systematic review and mixed treatment comparison: dressings to heal diabetic foot ulcers. Diabetol 2012; 55(7): 1902-1910.

3. Webster J, Liu Z, Norman G, Dumville JC, Chiverton L, Scuffham P, et al . Negative pressure wound therapy for surgical wounds healing by primary closure. Cochrane Database Syst Rev 2019; 3(3): CD009261.

4. Brocco E, Ninkovic S, Marin M, Whisstock C, Bruseghin M, Boschetti $G$, et al. Diabetic foot management: multidisciplinary approach for advanced lesion rescue. J Cardiovasc Surg (Torino) 2018; 59(5): 670684.

5. Hurd T, Trueman P, Rossington A. Use of a portable, single-use negative pressure wound therapy device in home care patients with low to moderately exuding wounds: a case series. Ostomy Wound Manag 2014; 60(3): 30-36.

6. Hudson DA, Adams KG, Huyssteen AV, Martin R, Huddleston EM. Simplified negative pressure wound therapy: clinical evaluation of an ultraportable, no-canister system. Int Wound J 2015; 12(2): 195201.

7. Patmo AS, Krijnen P, Tuinebreijer WE, Breederveld RS. The effect of vacuum-assisted closure on the bacterial load and type of bacteria: a systematic review. Adv Wound Care 2014; 3(5): 383-389.

8. Hasan MY, Teo R, Nather A. Negative-pressure wound therapy for management of diabetic foot wounds: a review of the mechanism of action, clinical applications, and recent developments. Diabet Foot Ankle 2015; 6(10): 1-10.

9. Karatepe O, Eken I, Acet E, Unal O, Mert M, Koc B, et al. Vacuum assisted closure improves the quality of life in patients with diabetic foot. Acta Chir Belg 2016; 111(5): 298-302.

10. Mohseni S, Aalaa M, Atlasi R, Mohajeri-Tehrani MR, Sanjari M, Amini MR. The effectiveness of negative pressure wound therapy as a novel management of diabetic foot ulcers: an overview of systematic reviews. J Diabetes Metab Disord 2019; 18(2): 625-641.

11. Lone AM, Zaroo MI, Laway BA, Pala NA, Bashir SA, Rasool A. Vacuum-assisted closure versus conventional dressings in the management of diabetic foot ulcers: a prospective case-control study. Diabet Foot Ankle 2014; 5(10): 1-5.

12. Dowsett C, Grothier L, Henderson V, Leak K, Milne J, Davis L, et al. Venous leg ulcer management: single use negative pressure wound therapy. Br J Community Nurs 2013; 18(6): 8-10.

13. Chan SY, Wong KL, Lim JX, Tay YL, Nather A. The role of RenasysGO in the treatment of diabetic lower limb ulcers: a case series. Diabet Foot Ankle 2014; 5(1): 1-6.

14. Nain PS, Uppal SK, Garg R, Bajaj K, Garg K. Role of negative pressure wound therapy in healing of diabetic foot ulcers. J Surg Tech Case Rep 2011; 3(1): 17-22.

15. Ravari H, Modaghegh MH, Kazemzadeh GH, Johari HG, Vatanchi AM, Sangaki A, et al. Comparision of vacuum-asisted closure and moist wound dressing in the treatment of diabetic foot ulcers. J Cutan Aesthet Surg 2013; 6(1): 17-20.

16. Seo SG, Yeo JH, Kim JH, Kim J, Cho T, Lee DY. Negative-pressure wound therapy induces endothelial progenitor cell mobilization in diabetic patients with foot infection or skin defects. Exp Mol Med 2013; 45(11): 1-5.

17. Liu Z, Dumville JC, Hinchliffe RJ, Cullum N, Game F, Stubbs N, et al. Negative pressure wound therapy for treating foot wounds in people with diabetes mellitus. Cochrane Database Syst Rev 2018; 10(10): CD010318.

18. Armstrong DG, Marston WA, Reyzelman AM, Kirsner RS. Comparative effectiveness of mechanically and electrically powered negative pressure wound therapy devices: a multicenter randomized controlled trial. Wound Repair Regen 2012; 20(3): 332-341. 